\title{
GC/MS Analysis of Gossypitrin Sample with Antioxidant and Neuroprotective Effects against Chemical Hypoxia-Induced PC $_{12}$ Cell Death
}

\author{
José González ${ }^{*}$, María A. Bécquer-Viart², Armando Cuéllar ${ }^{1}$, Julio Pérez ${ }^{3}$, Max Monan $^{4}$ \\ ${ }^{1}$ Departamento de Farmacia, Instituto de Farmacia y Alimentos, Universidad de La Habana, Calle 222, \# 231 e/23 \\ y 31, La Coronela, La Lisa, CP 13600, La Habana, Cuba. \\ ${ }^{2}$ Centro de Estudio para las Investigaciones y Evaluaciones Biológicas, Instituto de Farmacia y Alimentos, \\ Universidad de La Habana, Calle 222, \# 2317 e/23 y 31, La Coronela, La Lisa, CP 13600, La Habana, Cuba. \\ ${ }^{3}$ Centro Nacional de Toxicología, Hospital Militar "Carlos J. Finlay", Calle 114 y 31, Marianao, CP 11500, La \\ Habana, Cuba. \\ ${ }^{4}$ Association pour la Recherche sur la Valorisation des Ressources Naturelles de la Martinique (ARVARNAM), 16 \\ lot. les Rosiers, Quartier Thoraille, 97215, Rivière-Salée, Martinique, France. \\ ${ }^{*}$ E-mail: jgyaque@ifal.uh.cu
}

\begin{abstract}
Gossypitrin, a natural occurring flavonoid and the main bioactive substance from the flowers of Talipariti elatum Sw. (Blue Mahoe), is traditionally used in Cuba as expectorant and antasthmatic. It was analyzed by GC/MS using BSTFA as derivatization agent to get information about the chemical components present in the sample. Gas Chromatography Mass Spectrometry (GC-MS) analysis revealed the presence of another five different chemical compounds. According to NIST21 and NIST107 Libraries Databases the phytocompounds screened were D-Turanose, Thymol$\beta$-d-glucopyranoside, Ribitol, 2-Deoxy ribose and Hydroquinone- $\beta$-d-glucopyranoside. In addition, the structures of another 13 compounds have been identified by GC/MS experiments after isolation in $T$. elatum in this sample for the first time.
\end{abstract}

Keywords: Gossypitrin, Talipariti elatum, GC/MS, chemical components, flavonoid.

\section{Introduction}

In the early 90s the antioxidant activity of flavonoids was extensively studied in vitro, and it was assumed that such activity would be at the basis of the health promoting benefits of these compounds. However, in the late 90s and early 2000s the metabolism of flavonoids was deeply scrutinized, and the results indicated that their antioxidant activity in vivo could not account for the overall actions attributed to them (Fraga et al., 2010). The paradigm for flavonoid action changed towards the establishment of flavonoids as inflammation modulators, and more recently their role in neuroprotection, memory and cognition has been under scrutiny (Gomes et al., 2008; Spencer et al., 2009; Spencer, 2010).

Flavonoids, one of the most potent naturally occurring antioxidants, represent the most common group of polyphenolic compounds in the human diet and are widely distributed in plants. Recently, there has been great interest in the potential of flavonoids to protect the brain from ischemic damage (Panickar and Jang, 2013; Pérez-Hernández et al., 2016).

Flavonoids contained in berries may have a positive effect against Parkinson's disease and may help to improve memory in elderly people. Intake of antioxidant flavonoids has been inversely related to the risk of incidence of dementia (Commenges et al., 2000). Brain ischemia and particularly reperfusion induce generation of powerful free radicals such as superoxide and hydroxyl radicals, which overwhelm endogenous antioxidative mechanisms (Allen and Bayraktutan, 2009; Manzanero et al., 2013; Zhao et al., 2016). This condition of oxidative stress in the highly vulnerable brain tissue leads to lipid peroxidation, protein oxidation, different types of DNA damage, and eventually to neuronal cell death. In this sense, antioxidants of varying chemical structures have been investigated as therapeutic agents in the treatment of this acute injury (Alonso-Alconada et al., 2013; Ren et al., 2015).

Mechanisms of antioxidant action can include (1) suppression of ROS (reactive oxygen species) 
formation either by inhibition of enzymes or by chelating trace elements involved in free radical generation; (2) scavenging ROS; and (3) upregulation or protection of antioxidant defenses. Flavonoid action involves most of the mechanisms mentioned above. Some of the effects mediated by them may be the combined result of radical scavenging activity and the interaction with enzyme functions. Flavonoids inhibit the enzymes involved in ROS generation, that is, microsomal monooxygenase, glutathione Stransferase, mitochondrial succinoxidase, NADH oxidase, and so forth (Kumar and Pandey, 2013).

Gossypitrin, the main flavonoid glycoside isolated and characterized from ethanolic extracts of the petals of the flowers of Talipariti elatum Sw. (Malvaceae) possess good antioxidant properties. The most significant are against DPPH $(18,376 \mu \mathrm{g} / \mathrm{mL})$, TEAC $(2,14 \mathrm{mM})$, HOCL $(1,17 \pm 0,19 \mu \mathrm{M})$,

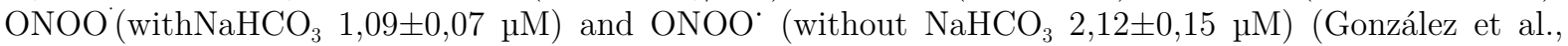
2017a). Its chelating properties against $\mathrm{FeCl}_{3}$ showed that this compound is able to form chelates with this pro-oxidant metal ion and also inhibit free radical generation (González et al., 2017b).

Gossypitrin was able to protect $\mathrm{PC}_{12}$ cells against hypoxia induced injury through direct free radical scavenging and modulation of endogenous antioxidants and antioxidant enzymes. In vitro antioxidant effects of gossypitrin on $\mathrm{PC}_{12}$ cells were higher than those of rutin, used as reference compound (Bécquer-Viart et al., 2018). The protective effects of gossypitrin in cells are probably the biological consequence of its antioxidant actions, evidenced by the gossypitrin capacity to restore the antioxidant enzyme activities (SOD and CAT) and to recover the endogenous GSH levels that could be used for the restorative activities of the cells (Bécquer-Viart et al., 2018). The aim of this research was to analyze the "sample of gossypitrin" used as protector of hypoxia induced injury by GC-MS using BSTFA as derivatization agent to get information about the chemical components present in the sample.

\section{Material and Methods}

\subsection{Plant Material}

Flowers were collected in January 2016 in the gardens of the Faculty of Pharmacy and Foods at Havana University after their mature. They were identified at the herbarium of National Botany Garden of Havana, where the voucher specimen no. HAJB 82587 was deposited and registered as Talipariti elatum S.w. Petals were separated manually from the rest of components of the flowers and packaged in a nylon bag strictly closely.

\subsection{Extract and Samples Preparation}

Dark red flowering types were collected daily. The petals used were dried in an oven with controlled temperature at $40^{\circ} \mathrm{C}$, during 5 days. The extracts were prepared with the ground material $(60 \mathrm{~g})$, using a Soxhlet apparatus and $95 \%$ ethanol $(675 \mathrm{~mL})$ for 20 hours. The ethanolic extracts were concentrated and roto-evaporated under vacuum to $200 \mathrm{~mL}$ at $120 \mathrm{rpm}, 70^{\circ} \mathrm{C}$, and $500 \mathrm{mbar}$. For to the purification, $1 \mathrm{~g}$ of solid was dissolved in $25 \mathrm{~mL}$ of diethyl ether and the volume was completed to $100 \mathrm{~mL}$ with ethanol. The sample was refrigerated until an abundant solid appear and it was recuperated to filtration. This process was done twice, to obtain only a yellowish-green solid monitoring by TLC on silica gel with fluorescent indicator $254 \mathrm{~nm}$ on aluminum cards (layer thickness $0.2 \mathrm{~mm})(10 \times 20 \mathrm{~cm})$ using n-butanol: acetic acid: water (4:1:5) as eluent (v/v/v) (Yaque et al., 2016).

\subsection{Isolation and HPLC Determination of Gossypitrin}

Experiments were carried out on a KNAUER spectrometer (Germany) equipped with an UV detector at $280 \mathrm{~nm}$ of length wave. A portion $(1 \mathrm{~mL})$ of this extract was dissolved in $50 \mathrm{~mL}$ of $\mathrm{MeOH}$ and separated

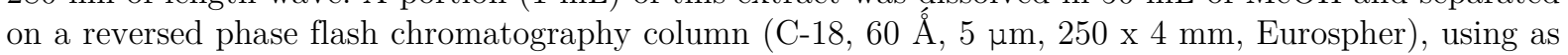
eluent $\mathrm{A} \mathrm{MeOH}$ and eluent $\mathrm{B} \mathrm{H}_{2} \mathrm{O}$. A gradient of $15-85 \% \mathrm{~B}$ during $30 \mathrm{~min}$ at $1 \mathrm{~mL} / \mathrm{min}$ was followed by holding the gradient, then increasing to $50 \%$ A during $10 \mathrm{~min}$, holding $10 \mathrm{~min}$, reversing to $0 \% \mathrm{~B}$ during $5 \mathrm{~min}$, and equilibrating for $5 \mathrm{~min}$. The determination of gossypitrin (G: compound 1) was also carried out from the solid residue dissolved in $50 \mathrm{~mL}$ of $\mathrm{MeOH}$, using the above described procedure (González et al., 2016). 


\subsection{IR Spectrometry of the Sample}

The IR spectrometric experiments were carried out on a Brucker IR model ALPHA (Germany) with a scan range $7500-360 \mathrm{~cm}^{-1}$, on $\mathrm{KBr}$ disks, spectral resolution $2 \mathrm{~cm}^{-1}$, diode laser $850 \mathrm{~nm}$ (Laser Class 1).

\subsection{GC-MS Procedures, Instrumentation and Parameters}

The samples were subjected to chromatographic analysis in equipment GC/MS, Shimadzu QP2010, equipped with a splitter split/splitless. With a BP5 $(30 \mathrm{~m} \times 0.25 \mathrm{~mm} \times 0.25$ microns $)$ capillary column under the following chromatographic conditions: Helium gas carrier obtained by electron impact fragments to a power of $70 \mathrm{eV}$ rate of $1.2 \mathrm{~mL} / \mathrm{min}, 1: 50$ split flow and the volume of injected sample of 1 ul. Programmed oven temperature: initial temperature was $70^{\circ} \mathrm{C}$ with a heating ramp of $10^{\circ} \mathrm{C} / \mathrm{min}$ to $300^{\circ} \mathrm{C}$ and remained stable at this temperature for 10 minutes. Subsequently the temperature was increased at a rate of $10^{\circ} \mathrm{C} /$ minute to $300^{\circ} \mathrm{C}$ for a total time of 78 minutes with an injector temperature $250^{\circ} \mathrm{C}$ and the interface temperature $300^{\circ} \mathrm{C}$ (Soledispa et al., 2018). The compounds were analyzed using GC/MS NIST21 and NIST107 library and having into account the results obtained after phytochemical screening according with González et al., 2017. Silylation agent was N, O-bis (trimethylsilyl) trifluoroacetamide (BSTFA) CAS 25561-30-2 Lot: 0901-1 Macherey-Nagel GmbH \& C. KG. Chromatographic running was done twice, with and without BSTFA.

\section{Results and Discussion}

The isolation and determination of gossypitrin presence in the sample by HPLC let us know the presence of 21 different chemical compounds; including gossypitrin which appear at 31.2 minutes of retention time (Fig. 1). The major peak corresponds to the flavonoid glucoside after several running of the sample and corroborating the structure of the compound by UV-Vis spectrum ( $\mathrm{Lu}$ et al., 2007; González et al., 2016). This result expresses that the flavonoid glycoside is not alone in the sample that was considered pure, indicating that the purification process does not allow separate $\mathbf{G}$ from the rest of chemical compounds that are accompanied at this flavonoid in the extracts.

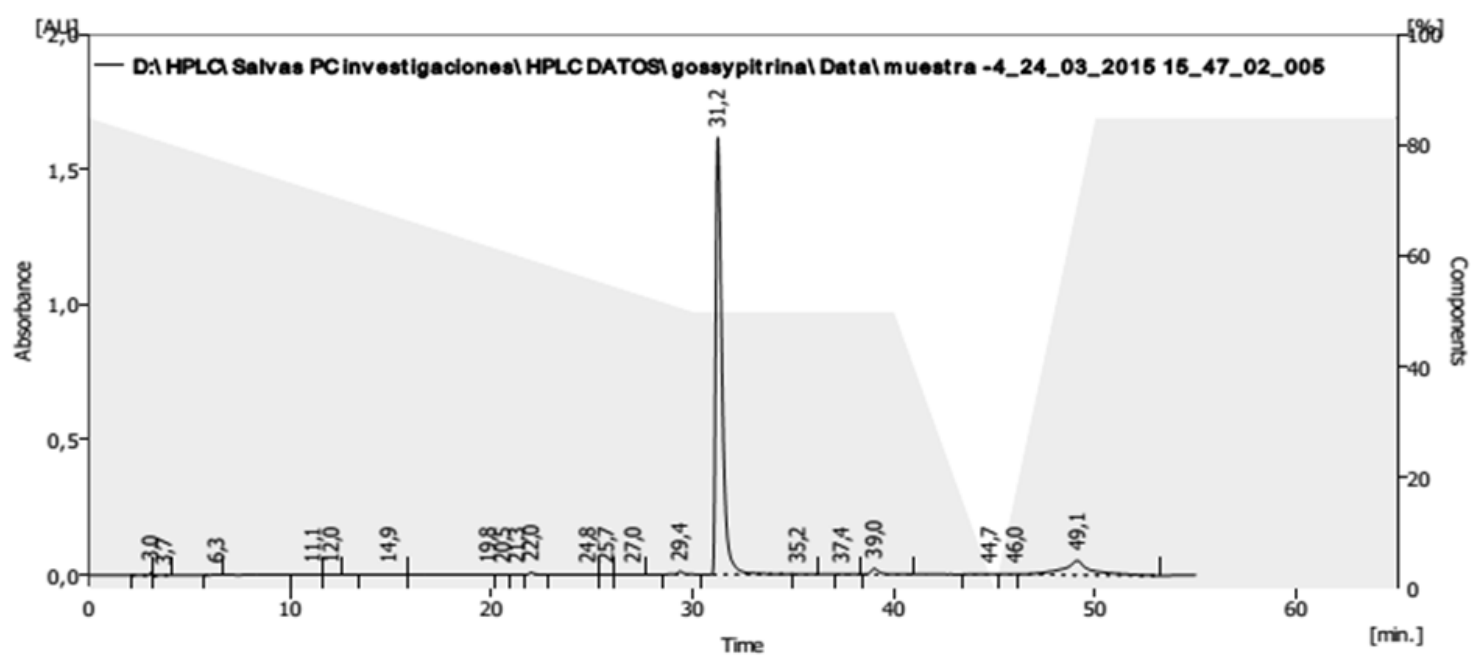

Figure 1. Current chromatographic profile of gossypitrin sample by HPLC.

Figure 2 shows the IR spectrum having typical presence of associated hydroxyl groups ${ }^{\mathrm{a}}$, alkyl groups $\mathrm{s}^{\mathrm{b}}$, carbonyl group ${ }^{\mathrm{c}}$ and aromatic rings ${ }^{\mathrm{d}}$ due to different bands at $3415 \mathrm{~cm}^{-1 \mathrm{a}} ; 2928 \mathrm{~cm}^{-1 \mathrm{~b}} ; 1656 \mathrm{~cm}^{-1 \mathrm{c}} ; 1610$, 1600,1569 and $1519 \mathrm{~cm}^{-1 \mathrm{~d}}$. Stretching C-O band is around $1200 \mathrm{~cm}^{-1}$. According with these results and data in literature we suggested that compound 1 to be a flavonol (Li et al., 2011; Erdogdu et al., 2010). 


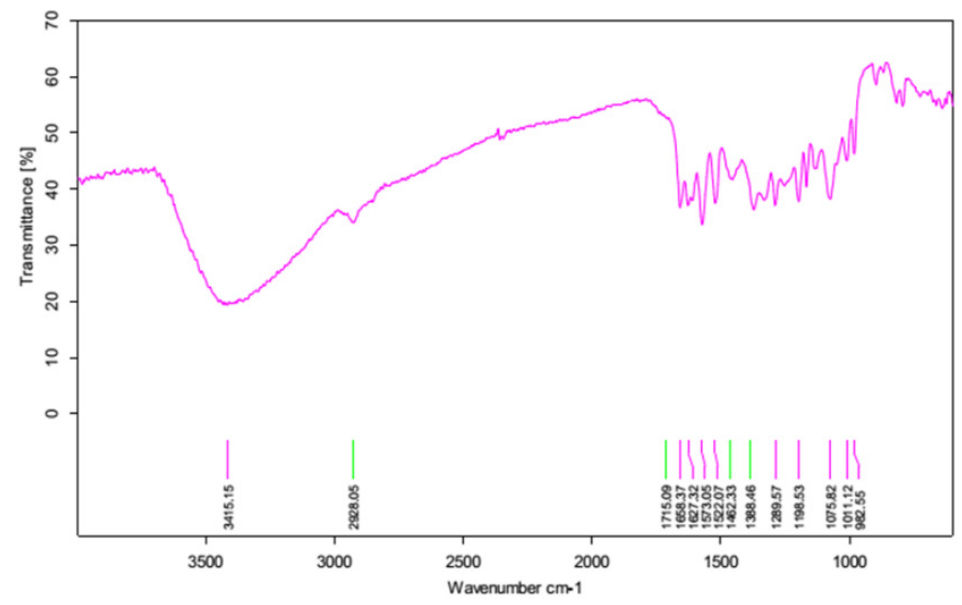

Figure 2. IR spectrum of gossypitrin in $\mathrm{KBr}$.

Figures 3 and 4 show the corresponding GC current chromatograms of the sample with and without Peak Integrate for TIC (All Group) using TMS (BSTFA). It is really appreciated that a lot of chemical constituents are present in the sample, corroborating the result obtained in the HPLC analysis. It is also easily observable that the current chromatogram has two distinctive zones, the first one between 15 and 50 minutes of retention time, and the second one, between 65 and 77 minutes of retention time. That last one, have the most clear observable peaks in the sample (Fig. 5).

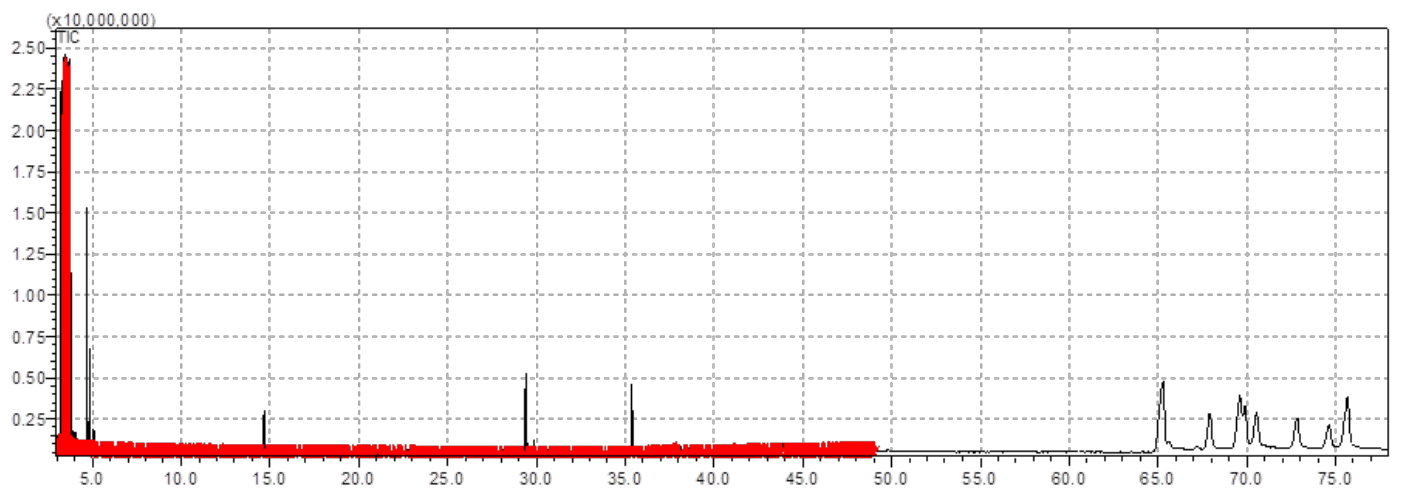

Figure 3. Gas Chromatogram of gossypitrin sample with Peak Integrate using TMS.

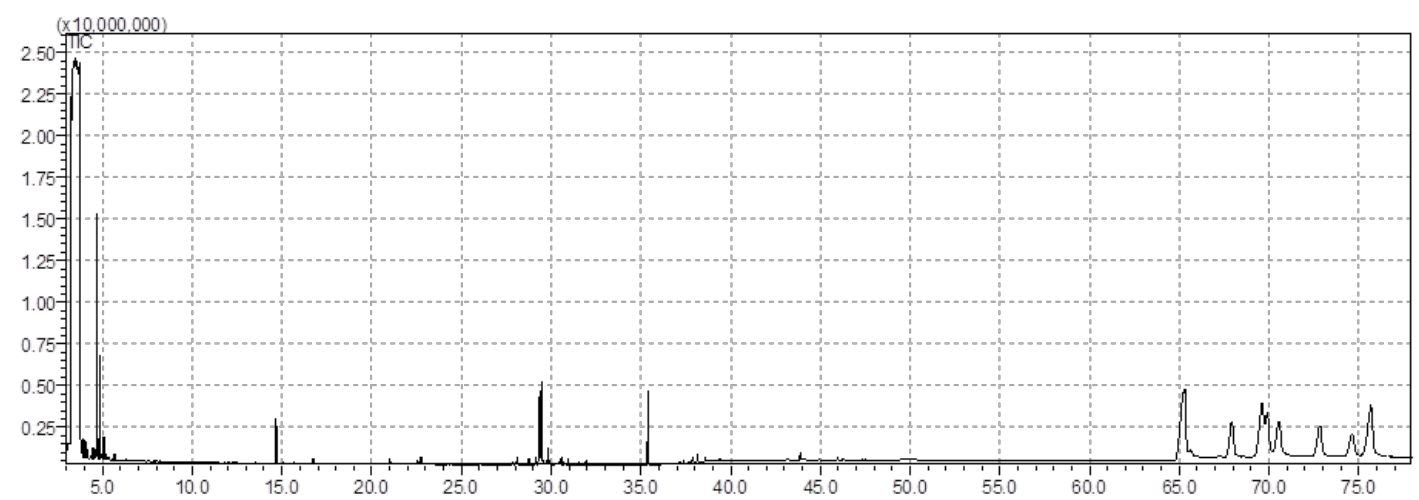

Figure 4. Current chromatogram of gossypitrin sample with TMS without Peak Integrate for TIC (All Group). 


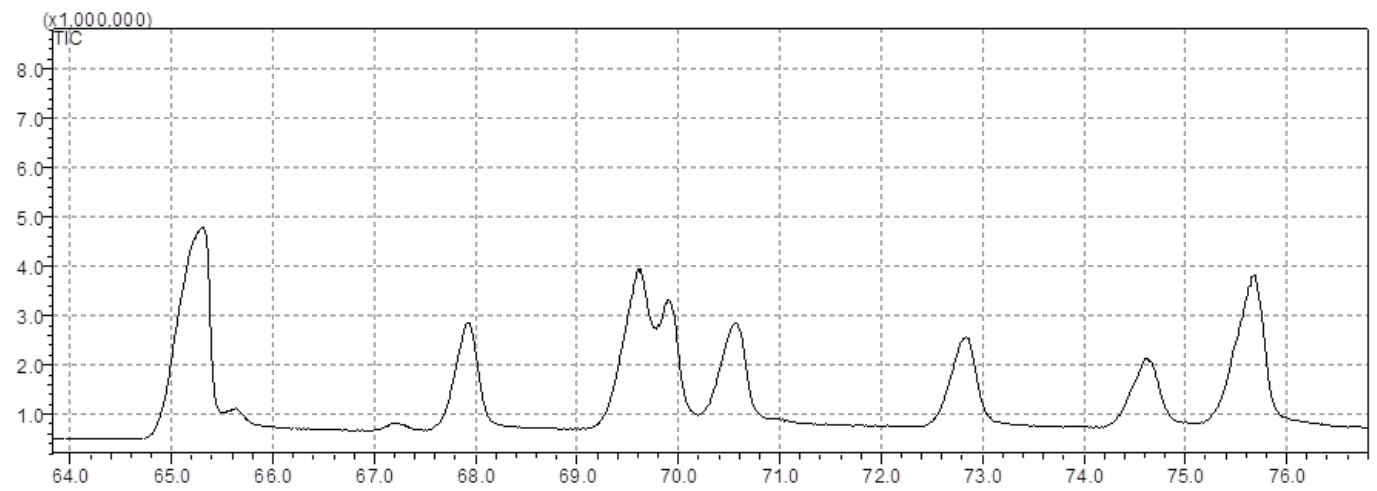

Figure 5. Gas Chromatogram of gossypitrin sample with TMS (65-77 min of Retention time).

Eight chemical components were tentatively identified by GC-MS, although only five chemical compounds were present in the sample, because three of them, were repeated in different retention time. They were: D-Turanose, Thymol- $\beta$-d-glucopyranoside and hydroquinone- $\beta$-d-glucopyranoside. Table 1 shows the results.

Table 1. Chemical compounds found between 65 and 77 minutes of Retention time.

\begin{tabular}{llllll}
\hline Peak & Ret. time & $\begin{array}{l}\text { Molecular } \\
\text { Weight }\end{array}$ & Base Peak & $\begin{array}{c}\text { Molecular } \\
\text { Formula }\end{array}$ & Compound Name \\
\hline $\mathbf{1}$ & 65.290 & 846 & 73 & $\mathrm{C}_{33} \mathrm{H}_{78} \mathrm{O}_{11} \mathrm{Si}_{7}$ & D-Turanose \\
$\mathbf{2}$ & 67.928 & 600 & 73 & $\mathrm{C}_{28} \mathrm{H}_{56} \mathrm{O}_{6} \mathrm{Si}_{4}$ & Thymol- $\beta$-d-glucopyranoside \\
$\mathbf{3}$ & 69.629 & 846 & 73 & $\mathrm{C}_{33} \mathrm{H}_{78} \mathrm{O}_{11} \mathrm{Si}_{7}$ & D-Turanose \\
$\mathbf{4}$ & 69.941 & 512 & 73 & $\mathrm{C}_{20} \mathrm{H}_{52} \mathrm{O}_{5} \mathrm{Si}_{5}$ & Ribitol \\
$\mathbf{5}$ & 70.566 & 350 & 73 & $\mathrm{C}_{14} \mathrm{H}_{34} \mathrm{O}_{4} \mathrm{Si}_{3}$ & 2-Deoxy ribose \\
$\mathbf{6}$ & 72.840 & 600 & 73 & $\mathrm{C}_{28} \mathrm{H}_{56} \mathrm{O}_{6} \mathrm{Si}_{4}$ & Thymol- $\beta$-d-glucopyranoside \\
$\mathbf{7}$ & 74.645 & 560 & 73 & $\mathrm{C}_{24} \mathrm{H}_{48} \mathrm{O}_{7} \mathrm{Si}_{4}$ & Hydroquinone- $\beta$-d-glucopyranoside \\
$\mathbf{8}$ & 75.687 & 560 & 73 & $\mathrm{C}_{24} \mathrm{H}_{48} \mathrm{O}_{7} \mathrm{Si}_{4}$ & Hydroquinone- $\beta$-d-glucopyranoside \\
\hline
\end{tabular}

Table 2. Chemical compounds found between 15 and 50 minutes of Retention time.

\begin{tabular}{|c|c|c|c|c|}
\hline $\begin{array}{l}\text { Ret. } \\
\text { time }\end{array}$ & Compound Name & $\begin{array}{l}\text { Molecular } \\
\text { Formula } \\
\end{array}$ & $\begin{array}{l}\text { Molecular } \\
\text { Weight }\end{array}$ & $\begin{array}{l}\text { Base } \\
\text { Peak }\end{array}$ \\
\hline 14.671 & Trimethylsilyl ether of glycerol & $\mathrm{C}_{12} \mathrm{H}_{32} \mathrm{O}_{3} \mathrm{Si}_{3}$ & 308 & 73 \\
\hline 16.799 & Butenedioic acid (Z)-, bis(trimethylsilyl) ester & $\mathrm{C}_{10} \mathrm{H}_{20} \mathrm{O}_{4} \mathrm{Si}_{2}$ & 260 & 147 \\
\hline 21.014 & Butanedioic acid, oxo(trimethylsilyl)-, bis(trimethylsilyl) ester & $\mathrm{C}_{13} \mathrm{H}_{28} \mathrm{O}_{5} \mathrm{Si}_{3}$ & 348 & 73 \\
\hline 22.561 & L-Proline, 5-oxo-1-(trimethylsilyl)-, trimethylsilyl ester & $\mathrm{C}_{11} \mathrm{H}_{23} \mathrm{NO}_{3} \mathrm{~S}_{\mathrm{i} 2}$ & 273 & 153 \\
\hline 22.758 & Threitol, 1,2,3,4-tetrakis-O-(trimethylsilyl) & $\mathrm{C}_{16} \mathrm{H}_{42} \mathrm{O}_{4} \mathrm{Si}_{4}$ & 410 & 73 \\
\hline 27.861 & D-Arabinonic acid, 2,3,5-tris-O-(trimethylsilyl)-, gamma.-lactone & $\mathrm{C}_{14} \mathrm{H}_{32} \mathrm{O}_{5} \mathrm{Si}_{3}$ & 364 & 73 \\
\hline 28.027 & Ribitol, 1,2,3,4,5-pentakis-O-(trimethylsilyl) & $\mathrm{C}_{20} \mathrm{H}_{52} \mathrm{O}_{5} \mathrm{Si}_{5}$ & 512 & 73 \\
\hline 28.112 & Glucofuranoside, methyl 2,3,5,6-tetrakis-O-(trimethylsilyl)-, .alpha.-D & $\mathrm{C}_{19} \mathrm{H}_{46} \mathrm{O}_{6} \mathrm{Si}_{4}$ & 482 & 217 \\
\hline 29.269 & Benzoic acid, 3,4-bis[(trimethylsilyl)oxy]-, trimethylsilyl ester & $\mathrm{C}_{16} \mathrm{H}_{30} \mathrm{O}_{4} \mathrm{Si}_{3}$ & 370 & 73 \\
\hline 29.341 & Mannoonic acid, 2,3,5,6-tetrakis-O-(trimethylsilyl)-, lactone & $\mathrm{C}_{18} \mathrm{H}_{42} \mathrm{O}_{6} \mathrm{Si}_{4}$ & 466 & 73 \\
\hline 29.454 & 2-Keto-d-gluconic acid, pentakis(trimethylsilyl) & $\mathrm{C}_{21} \mathrm{H}_{50} \mathrm{O}_{7} \mathrm{Si}_{5}$ & 554 & 73 \\
\hline 31.559 & Glucose, pentakis-O-trimethylsilyl & $\mathrm{C}_{21} \mathrm{H}_{52} \mathrm{O}_{6} \mathrm{Si}_{5}$ & 540 & 73 \\
\hline 31.937 & Dodecanoic acid, trimethylsilyl ester & $\mathrm{C}_{15} \mathrm{H}_{32} \mathrm{O}_{2} \mathrm{Si}$ & 272 & 73 \\
\hline 35.386 & Hexanedioic acid, bis(2-ethylhexyl) ester & $\mathrm{C}_{22} \mathrm{H}_{42} \mathrm{O}_{4}$ & 370 & 129 \\
\hline
\end{tabular}

The first zone examined contained 14 different chemical metabolites listed in Table 2, giving an idea that the sample was formed by 19 different chemical substances in general. Only Ribitol was repeated in 
the sample taking into account both retention time zones (15-50 and 65-77 minutes). Summarizing, eighteen different chemical components those were present in ethanolic extract of red petals from $T$. elatum Sw. in Cuba.

As it could see gossypitrin was not present in mentioned compounds. Multiple peaks of one and the same metabolite, i.e., with different degree of TMS silylation of the original molecule, might be detected. This is particularly true for those metabolites with several functional groups such as amino acids ($\left.\mathrm{COOH},-\mathrm{NH}_{2},-\mathrm{OH}\right)$, flavonoid glycosides and monosaccharides which carry a high number of hydroxyl groups (Rohloff, 2015).

The fact is that this compound is a flavonoid glucoside and it is necessary to be derivatized to be registered in the chromatogram, because it is a non-volatile compound by itself. The sample was running with and without derivatization, this condition permitted that in the first case $\mathbf{G}$ couldn't be detectable. It is easy to understand that this is due to the molecular mass of the compound that was increased up to 1128 u.m.a., because the compound has at least, 9 active hydrogens which might be exchanged by TMS groups and the equipment only can detect molecules with molecular masses up to 1079 u.m.a (Fig.6).<smiles>CC(O)C(O)C(O)Oc1cc(O)c2c(=O)c(O)c(-c3ccc(O)c(O)c3)oc2c1O</smiles>

Figure 6. Structure scheme of flavonoid Gossypitrin from red petals of T. elatum.

Obviously, it is necessary to realize the acidic hydrolysis of this flavonoid glucoside separates the aglycone from the sugar moiety and then, with the pure aglycone, gets the mass/charge of this natural product. Another possibility is the use of HPLC-MS due to Mass Spectrometry (MS) has proved to be one of the most effective techniques in biomedical research, in special when complex matrixes of biological samples must be analyzed (Pinheiro P. F, and Justino G. C., 2012).

\section{Conclusion}

For the first time, the chemical characterization of a sample of gossypitrin used in the research of antioxidant and neuroprotective effects against chemical hypoxia-induced $\mathrm{PC}_{12}$ cell death was made by GC-MS. From the sample were isolated and characterized eighteen different chemical components that were present in ethanolic extract of red petals from T. elatum Sw. in Cuba. Gossypitrin the majoritarian flavonoid glucoside that was isolated and characterized by our research team was not found because of the high molecular weight reached for it when the sample is derivatized. Hence this study provides useful information for the identification of this plant for the future plan and also gives standardization parameters for the development of flower formulation.

\section{Conflict of Interest}

The authors declare no conflict of interest.

\section{References}

1. Allen CL, Bayraktutan U (2009) Oxidative stress and its role in the pathogenesis of ischemic stroke. Int J Stroke 4: 461-470.

2. Alonso-Alconada D, Alvarez A, Arteaga O, Martínez-Ibargüen A, Hilario E (2013). Neuroprotective effect of melatonin: a novel therapy against perinatal hypoxia ischemia. Int J Mol Sci 14: 9379-9395. 
3. Bécquer-Viart MA, González-Yaque J, Fonseca-Fonseca LA, Núñez-Figueredo Y, Pardo Andreu GL. (2018). Antioxidant and neuroprotective effects of gossypitrin, a flavonoid from Talipariti elatum, against chemical hypoxia-induced PC12 cell death. J Pharm Pharmacogn Res 6(2): 72-80.

4. Commenges D., V. Scotet, S. Renaud, H. Jacqmin-Gadda, P. Barberger-Gateau, and J. F. Dartigues. (2000). "Intake of flavonoids and risk of dementia". The European Journal of Epidemiology, vol.16, no. 4, pp. 357-363.

5. Erdogdu, Y.; Unsalan, O.; Sajan, D. \& Gulluoglu, M.T. (2010). Structural conformations and vibrational spectral study of chloroflavone with density functional theoretical simulations. Spectrochimica Acta Part A: Molecular and Biomolecular Spectroscopy, 76, 2, 130-136.

6. Fraga, C.G.; Galleano, M.; Verstraeten, S.V. \& Oteiza, P.I. (2010). Basic biochemical mechanisms behind the health benefits of polyphenols. Molecular Aspects of Medicine, 31, 6, 435-445.

7. Gomes, A.; Fernandes, E.; Lima, J.L.F.C.; Mira, L. \& Corvo, M.L. (2008) Molecular Mechanisms of AntiInflammatory Activity Mediated by Flavonoids, Current Medicinal Chemistry, 15, 1586-1605.

8. González J., Cuéllar A., Abreu P., Monan M., Nossin E., and François-Haugrin F. (2017). Antioxidant Activity of gossypitrin isolated from the petals of Talipariti elatum (Sw.) Fryxell (Malvaceae) in Cuba. International Journal of Engineering Research \& Science (IJOER). Vol-3, Issue-10, October- 2017, pp. 17-22.

9. González J., Cuéllar A., Gómez E., Dopico E., Vázquez R., de Armas T. (2017). EVALUACIÓN FARMACOGNÓSTICA Y FITOQUÍMICA PRELIMINAR DE LOS PISTILOS CON POLEN, LA CORTEZA Y LA MADERA DE TALIPARITI ELATUM SW. Revista de Ciencias Farmacéuticas y Alimentarias. Vol.3 / №.2. pp. 1-6. ISSN: 2411-927X / RNPS: 2396

10. González J., Cuéllar A., Nossin E., \& Max Monan M. (2017). Iron Chelating Activity of Gossypitrin Isolated from the Petals of Talipariti elatum Sw. (Fryxell) Malvaceae. Journal of Agricultural Studies. Vol. 5, No. 2. Pp. 1-12. ISSN 2166-0379

11. González J., Romero J. A., Cuéllar A., Monan M., Nossin E., and François-Haugrin F. (2016). HPLC Analysis of the Total Extract and Gossypitrin Isolated from the Petals of Talipariti elatum (S.w) Fryxell (Malvaceae). Int.J.Curr.Res.Aca.Rev.4 (7): 89-95. doi: http://dx.doi.org/10.20546/ijcrar.2016.407.011

12. Kumar S. and Abhay K. Pandey. (2013). Chemistry and Biological Activities of Flavonoids: An Overview. Hindawi Publishing Corporation. The Scientific World Journal. Volume 2013, Article ID 162750, 16 pages http://dx.doi.org/10.1155/2013/162750

13. Li, X.-H., Liu, X.-R.; Zhang, X.-Z. 2011. Molecular structure and vibrational spectra of three substituted 4thioflavones by density functional theory and ab initio Hartree-Fock calculations. Spectrochimica Acta Part A: Molecular and Biomolecular Spectroscopy, 78, 1, 528-536.

14. Lu, Y., Yu, K., Qu, H.B., Cheng, Y.Y. 2007. Development of an HPLC-UV-ELSD method for quantification of multiple components of a Chinese medicine made from radix Salvia miltiorrhiza and Panax notoginseng. Chromatographia, 65: 19-24.

15. Manzanero S, Santro T, Arumugam TV. (2013). Neuronal oxidative stress in acute ischemic stroke: sources and contribution to cell injury. Neurochem Int 62: 712-718.

16. Panickar KS, Jang S (2013). Dietary and plant polyphenols exert neuroprotective effects and improve cognitive function in cerebral ischemia. Recent Pat Food Nutr Agric 5: 128-143.

17. Pérez-Hernández J, Zaldívar-Machorro VJ, Villanueva-Porras D, Vega-Ávila E, Chavarría A (2016). A potential alternative against neurodegenerative diseases: Phytodrugs. Oxid Med Cell Longev 2016: 8378613.

18. Pinheiro P. F and Justino G. C. (2012). Structural Analysis of Flavonoids and Related Compounds - A Review of Spectroscopic Applications. Phytochemicals - A Global Perspective of Their Role in Nutrition and Health. Edited by Dr Venketeshwer Rao. Pp. 33-56. ISBN: 978-953-51-0296-0, InTech.

19. Ren Y, Wei B, Song X, An N, Zhou Y, Jin X, Zhang Y. (2015.) Edaravone's free radical scavenging mechanisms of neuroprotection against cerebral ischemia: review of the literature. Int J Neurosci 125: 555-565.

20. Rohloff J. (2015). Analysis of Phenolic and Cyclic Compounds in Plants Using Derivatization Techniques in Combination with GC-MS-Based Metabolite Profiling. Molecules, 20, 3431-3462; doi:10.3390/molecules20023431

21. Soledispa P. A., González J., Cuéllar A., Pérez J., Monan M. (2018). GC-MS Chemical Characterization of Main Components of Smilax Domingensis Wild. in Cuba. Journal of Agricultural Studies. Vol. 6, No. 2. 79-86. ISSN 2166-0379

22. Spencer, J.P. (2010). The impact of fruit flavonoids on memory and cognition. British Journal of Nutrition, 31, $6,546-557$. 
23. Spencer, J.P.; Vauzour, D. \& Rendeiro, C. (2009). Flavonoids and cognition: the molecular mechanisms underlying their behavioral effects. Archives of Biochemistry and Biophyics, 492, 1-2, 1-9.

24. Yaque, J.G., Cuéllar, A., Massi, L., Monan, M., Nossin, E. and François-Haugrin, F. (2016). Isolation and Characterization of Flavonols by HPLC-UV-ESI-MS/MS from Talipariti elatum S.w. American Journal of Plant Sciences, 7, 1198-1204. 